\title{
PENGEMBANGAN SISTEM APLIKASI MULTIMEDIA INTERAKTIF PADA PELAJARAN (FISIKA ENERGY) UNTUK TINGKAT SEKOLAH MENENGAH ATAS
}

\author{
Lukman Anas ${ }^{1}$
}

\section{Info Artikel}

Sejarah Artikel:

Diterima: 25 Februari 2019

Direvisi: 15 Maret 2019

Dipublikasikan: April 2019

e-ISSN: 2620-3081

p-ISSN: 1411-2744

DOI: https://doi.org/10. 21009/itp.v21i1.10570

\begin{abstract}
On learning of physics required a thorough understanding of the concept that students can solve a problem in physics with good.Then destination to improve the quality of student learning, researchers will create a physics-based learning development is complex interactive multimedia on the subject of physics. Multimedia development that will be developed later with the Method (MDLC) Multimedia Development Life Cycle to have six stages, namely, concept, design, content collecting material, assembly, testing and distribution, to eventually used in the development of interactive media more particularly on the subject of physics. By results of data analysis showed an increase in the first cycle of $7.69 \%$ and the second cycle of $9.12 \%$. Increased student learning outcomes is because during the learning process, teachers use interactive multimedia learning.
\end{abstract}

Keywords: multimedia, physics, the subject physics, interactive, learning

\begin{abstract}
Abstrak: Pada pembelajaran fisika dibutuhkan suatu pemahaman konsep yang matang agar siswa dapat memecahkan suatu permasalahan dalam bidang fisika dengan baik. Maka tujuan untuk meningkatkan kualitas pembelajaran para siswa, peneliti akan membuat pengembangan pembelajaran fisika berbasis multimedia interaktif yang bersifat kompleks pada pelajaran fisika pokok bahasan energy. Pengembangan multimedia yang nantinya akan di kembangkan yaitu dengan Metode (MDLC) Multimedia Development Life Cycle yang memiliki 6 tahapan yaitu, concept, design, collecting content material, assembly, testing dan distribution, untuk nantinya digunakan dalam pengembangan media interaktif lebih lanjut khususnya pada pelajaran fisika pokok bahasan energy. Berdasarkan hasil analisis data menunjukkan terjadi peningkatan pada siklus I sebesar 7,69\% dan pada siklus II sebesar 9,12\%. Meningkatnya hasil belajar siswa tersebut disebabkan karena selama proses pembelajaran, guru menerapkan pembelajaran multimedia interaktif.
\end{abstract}

Kata kunci: Multimedia, Fisika, Pokok bahasan energy, Interaktif, Pembelajaran

(C) 2019 PPS Universitas Negeri Jakarta

\footnotetext{
${ }^{1}$ Fakultas Teknik, Universiitas Muhammadiyah Makassar, Jl. Sultan Alauddin No. 259 (Menara Iqra Lt.3) Makassar Sulawesi Selatan, lukmananas@unismuh.ac.id, 082188771991
} 


\section{PENDAHULUAN}

Paradigma pendidikan saat ini menuntut proses belajar-mengajar tentunya ada subjek dan objek yang berperan secara aktif, dinamik dan interaktif di dalam ruang belajar, baik di dalam kelas maupun di luar kelas. Pada realitanya, sampai sekarang ini para pendidik dalam praktiknya sering kali mengajar dengan menggunakan media yang sudah tersedia, yaitu textbook. Kurangnya kreativitas dan motivasi dari para pendidik dalam mengembangkan dan menciptakan media pembelajaran yang inovatif, membuat proses pembelajaran di kelas membosankan bagi siswa (Heru, 2010). Keadaan ini diperparah lagi dengan penggunaan strategi pembelajaran yang kurang menarik, kurang bervariasi, monoton dan cenderung ekspositori sehingga interaksi antara pendidik dengan peserta didik tidak dinamis. Hal ini mengakibatkan rendahnya kesempatan peserta didik untuk berinteraksi secara aktif dalam pembelajaran.

\section{Karakteristik Pelajaran Fisika SMA}

Materi IPA, khususnya Fisika, tidak dapat terlepas dari satu kesatuan yang terdiri atas proses, produk, dan sikap. Proses sains dalam mempelajari IPA akan berjalan sesuai dengan kaidah yang benar manakala subjek yang melaksanakan proses tersebut memiliki sikap ilmiah yang memadai. Sikap ilmiah yakni suatu kecenderungan seseorang untuk berperilaku dan mengambil tindakan pemikiran ilmiah yang sesuai dengan metode ilmiah. Dalam lingkup yang lebih luas, sikap ilmiah menjadi ciri kompetensi seorang Ilmuwan. Hal ini berarti bahwa seseorang dikatakan memiliki kompetensi seorang Ilmuwan jika pada dirinya ditemukan sikap ilmiah sebagai cerminan dari penghayatannya terhadap proses dan produk sains. Dengan demikian, sikap ilmiah sangat penting untuk diperhatikan guru dalam mempelajari sains, khususnya Fisika.

Kemampuan verbal juga merupakan salah satu faktor internal yang dapat mempengaruhi tinggi rendahnya prestasi belajar siswa. Dengan kemampuan verbal yang baik yang dimiliki oleh siswa, akan sangat mendukung dalam proses maupun hasil pembelajaran pada materi yang akan diajarkan. Hal ini bisa terjadi karena siswa yang memiliki kemampuan verbal yang baik diduga memiliki kecakapan yang mensyaratkan keakraban dengan bahasa tertulis maupun lisan untuk menyimak, menelaah isi dari suatu pernyataan, berani mengungkapkan ide, gagasan, pendapat, dan pikirannya, sehingga siswa tersebut dapat mengambil suatu kesimpulan yang tepat.

Selain keterlibatan faktor internal, karakteristik materi juga penting untuk diperhatikan. Dimana dalam memilih model pembelajaran yang tepat, guru harus memperhatikan kondisi siswa, sifat materi bahan ajar, dan fasilitas-media yang tersedia. Hal ini penting karena memang dalam membelajarkan konsep fisika yang kompleks, sangat penting bagi guru untuk memperhatikan sifat dan karakteristik materi bahan ajar yang akan disampaikan dalam proses pembelajaran. Apakah materi bahan ajar tersebut bersifat konkret ataupun yang bersifat abstrak. Karenanya, untuk menyampaikan materi bahan ajar fisika yang bersifat abstrak, tentu saja diperlukan pendekatan dan metode yang berbeda dengan yang konkret. Dengan harapan bahwa, diketahuinya karakteristik materi bahan ajar yang akan 
disampaikan tersebut dapat dijadikan sebagai acuan bagi guru untuk menentukan pendekatan, metode dan sarana bantu (media, atau alat peraga) pembelajaran yang relevan dengan karakteristik materi yang akan disampaikan. Hal ini, bertujuan untuk mempermudah dalam mengkomunikasikan materi fisika tersebut. Namun demikian, sebagian guru masih belum sepenuhnya memperhatikan sifat dan karakteristik materi fisika dalam menentukan pendekatan, metode dan sarana bantu pembelajaran yang relevan.

Ada beberapa materi bahan ajar fisika yang disampaikan di kelas IPA antara lain: Kinematika gerak, hukum Newton tentang gravitasi, hukum Hooke dan elastisitas, osilasi (getaran), usaha dan energi, hukum kelestarian energi mekanik, momentum dan impuls. Materi momentum dan impuls mencakup pengertian momentum, pengertian impuls, hukum kekekalan momentum, tumbukan, serta aplikasi impuls dan momentum. Karakteristik materi momentum dan impuls adalah salah satu materi fisika yang bersifat abstrak. Kendatipun konsep momentum dan impuls banyak dijumpai dan diaplikasikan dalam kehidupan sehari-hari, contohnya tumbukan. Namun demikian pada materi ini, siswa masih banyak yang mendapatkan nilai yang kurang memuaskan. Hal ini diduga diantaranya terjadi karena istilah momentum dan impuls pada umumnya jarang didengar oleh siswa dalam kehidupan sehari-hari. Sehingga untuk membelajarkan konsep momentum dan impuls harus divisualisasikan dengan sarana bantu (komputer dan video animasi/multimedia interaktif), dalam hal ini, diperlukan multimedia interaktif yang berkaitan dengan materi tersebut. Tujuannya adalah agar mempermudah mengkomunikasikan dan membangun konsep tentang materi tersebut. Selain itu, siswa juga diharapkan mampu mengaplikasikan pengetahuan yang telah diperolehnya dalam kehidupan sehari-hari. Dengan demikian, hasil belajar yang dicapai tentunya dapat lebih bermakna dan siswa mempunyai tujuan yang nyata dalam mengikuti pembelajaran.

Hakikat Ilmu Fisika merupakan ilmu yang diperoleh dan dikembangkan berdasarkan metode ilmiah dalam penyelesaian suatu masalah dan juga mencari jawaban atas pertanyaan apa, mengapa dan bagaimana gejala-gejala alam terjadi. Ketidakberhasilan siswa dalam menguasai Ilmu fisika khususnya materi momentum dan impuls kemungkinan disebabkan karena pengetahuan yang dibentuk siswa hanya berasal dari pengetahuan guru yang dipindahkan ke siswa. Siswa hanya menerima informasi dari guru tanpa keterlibatan siswa untuk memecahkan masalah dan mencari jawaban atas pertanyaan apa, mengapa dan bagaimana gejala-gejala alam terjadi. Akhirnya siswa belum bisa menghubungkan antara pengetahuan yang mereka pelajari dan proses pengaplikasian pengetahuan tersebut dalam kehidupan sehari-hari siswa.

Selain itu, yang perlu diperhatikan oleh guru adalah keterlibatan faktor internal yang dapat mempengaruhi prestasi belajar fisika siswa, antara lain: aktivitas belajar, gaya belajar, tingkat kecerdasan IQ, kreativitas, sikap ilmiah siswa, kemampuan verbal siswa, motivasi berprestasi siswa, dll. Meskipun faktor-faktor tersebut diketahui telah dapat mempengaruhi hasil prestasi belajar fisika siswa namun hal ini kurang diperhatikan oleh para guru. Studi penelitian untuk mengetahui pengaruh faktorfaktor tersebut terhadap prestasi belajar fisika siswa juga masih perlu untuk ditingkatkan. Dengan 
demikian, penting bagi guru untuk memperhatikan faktor-faktor yang berpengaruh terhadap prestasi belajar fisika siswa untuk dapat mencapai tujuan pembelajaran yang diinginkan. (Seok, 2008 ) menyatakan bahwa,

"e-learning is a new form of pedagogy for learning in the $21^{\text {st }}$ century. e-Teacher are e-learning instructional designer, facilitator of interaction, and subject matter experts".

Penerapan e-learning untuk pembelajaran online pada masa sekarang ini sangatlah mudah dengan memanfaatkan modul Learning Management System yang mudah untuk diinstalasi dan dikelola seperti Moodle.

\section{Perencanaan konsep pembelajaran}

Perencanaan pembelajaran pada dasar-nya merupakan gambaran mengenai beberapa aktivitas dan tindakan yang akan dilakukan pada saat berlangsungnya proses pembelajaran. Dengan demikian dapat disimpulkan, aplikasi perencanaan pembelajaran yang ber-basis e-learning memuat rencana, perkiraan dan gambaran umum kegiatan pembelajaran dengan memanfaatkan jaringan komputer, baik intranet maupun internet. Lingkup perencanaan pembelajaran meliputi empat komponen utama, yaitu tujuan, materi atau bahan ajar, kegiatan belajar mengajar, dan evaluasi. Hal tersebut sesuai dengan pernyataan (Sisco, 2010) yaitu:

E-learning solution/strategy: "An e-learning solution of strategy is composed of content, technology, and services. Content includes courses, curriculum, and knowledge or skills development modules. Technology is the method used to deliver the content, including the internet and teleconferencing. Services relate to maintenance, content upgrades, and technical upgrades to both delivery and content. Understanding these com-ponents is an important first step to understanding what e-learning is and how it is "delivered",".

Fungsi utama sistem pendidikan saat ini harus mendorong para peserta didik untuk mendapatkan pembelajaran yang diperlukan demi memenuhi kebutuhan peserta didik dalam mendapatkan pengetahuan (Pallares, 2013). Salah satu contoh yaitu pada mata pelajaran Fisika. Berdasarkan hasil wawancara dengan salah satu guru Fisika pada sekolah menengah atas, dalam mengembangkan proses mengajar di kelas, cenderung para pendidik (guru) kurang kreatif dan inovatif dalam menerapkan media pembelajaran saat mengajar. Selama ini media pembelajaran yang sering digunakan dalam menyampaikan materi yaitu textbook. Penelitian tentang image of man tentang bagaimana informasi diperoleh, disimpan dan diambil (Kirschner, Sweller and Clark, 2006) sementara menggunakan Power Point masih jarang diaplikasikan. Walaupun telah menggunakan beberapa media dalam menunjang proses pembelajaran akan tetapi hasil belajar siswa masih tergolong rendah. Hal tersebut ditunjukkan dari nilai rata-rata siswa pada mata pelajaran Fisika semester ganjil tahun pelajaran 2017/2018 masih banyak yang belum tuntas yaitu 70 dari Kriteria Ketuntasan minimal (KKM) yang ditetapkan, yaitu 75 . 
Beberapa permasalahan dalam pelaksanaan proses pembelajaran Fisika di sekolah menengah atas misalnya kurangnya motivasi dari peserta didik untuk mempelajari Fisika karena mata pelajaran Fisika dianggap sebagai mata pelajaran yang membosankan dan menjadi momok yang menakutkan, menjadi masalah yang harus diselesaikan yakni apa yang menjadi kebutuhan peserta didik dalam aplikasi melibatkan pendidik terkait penyesuaian mental dan realisasi pembelajaran yang berarti (Gurses and Dogar, 2013), sehingga berpengaruh pada hasil belajar siswa. Faktor eksternalnya seperti pembelajaran konvensional yang masih sering dilakukan oleh pendidik membuat pelajaran ini kurang begitu menarik.

\section{Konsep Pembelajaran Multimedia}

Konsep multimedia mendorong siswa untuk bekerja dalam kelompok, mengungkapkan pengetahuan mereka dalam berbagai cara, memecahkan masalah, merevisi karya mereka sendiri, dan membangun pengetahuan. Siswa memiliki kesempatan untuk belajar dan menerapkan keterampilan dunia nyata. Mereka belajar nilai kerja sama tim; dampak dan pentingnya media yang berbeda, termasuk masalah desain, media kesesuaian dan validitas, dan hukum hak cipta; tantangan berkomunikasi dengan peserta yang berbeda; pentingnya penelitian, perencanaan, dan keterampilan organisasi; pentingnya presentasi dan keterampilan berbicara; dan bagaimana menerima dan memberikan umpan balik yang konstruktif. Membuat proyek multimedia membantu untuk memperkuat keterampilan teknologi siswa dan mempersiapkan mereka untuk tuntutan karir masa depan.

Multimedia terdiri dari berbagai jenis media untuk menyampaikan pesan/informasi kepada pengguna sesuai tujuan dan fungsinya. Terdapat beberapa komponen utama multimedia yang dirangkai dalam format digital yang disusun sedemikian rupa sehingga menarik dan memotivasi pengguna untuk belajar. Komponen-komponen tersebut adalah teks, gambar, audio, video, dan animasi. Satu komponen lagi bisa ditambahkan yaitu interaktif, sehingga multimedia bisa disebut sebagai 'multimedia interaktif'.

Riset dalam pembelajaran seperti multimedia pembelajaran menjadi suatu kebutuhan dalam masyara- kat yang melek teknologi termasuk peserta didik. Untuk masuk dalam dunia mereka diperlukan skill yang menjembatani penyampaian pesan se-cara efektif dan efisien (Gunter, 2010). Dengan demikian harapan akan output yang baik dapat terwujud.

Beberapa penelitian terdahulu juga menunjukkan sejumlah kelebihan multimedia dalam pembelajaran fisika. (McKagan,2008) menemukan bahwa penggunaan multimedia efektif dalam pembelajaran konsep mekanika kuantum terbukti membantu mahasiswa membangun model mental dan intuisi tentang mekanika kuantum meliputi representasi visual dari konsep abstrak dan proses mikroskopik yang tidak dapat diobservasi secara langsung. Penelitian ini juga menunjukkan bahwa simulasi yang digunakan efektif dalam membantu mahasiswa belajar dan telah mengungkapkan pengertian baru yang mendalam baru pada cara pikir mereka tentang mekanika kuantum.

multimedia interaktif yang digunakan di dalam pembelajaran merupa-kan media yang sangat baik untuk meningkatkan proses belajar- dengan memberikan kesempatan bagi para mahasiswa dalam 
mengembangkan keterampilan, mengidentifikasi masalah, me-ngorganisasi, menganalisis, mengevaluasi, dan mengkomunikasikan informasi (Onintra, 2009).

Berbagai alternatif untuk memperbaiki kelemahan penerapan pembelajaran Fisika harus dilakukan dengan pemanfaatan media pembelajaran yang inovatif. Pengembangan self-regulation menjadi sangat penting karena itu memiliki dampak yang signifikan terhadap hasil pembelajaran (Bakracevic Vukman and Licardo, 2010). Dengan adanya media pembelajaran yang sesuai dengan kebutuhan dan karakteristik siswa, diharapkan dapat membuat pembelajaran akan berlangsung secara efektif dan efisien. Salah satu contoh media pembelajaran pendidikan modern saat ini adalah pengembangan multimedia learning. Manfaat dari teknologi pendidikan terkait dengan fakta bahwa itu semua dapat merangsang kemudahan dalam fenomena riil, dengan demikian mendukung bentuk pembelajaran yang lebih dekat dengan kehidupan personal peserta didik (Spires, Rowe, Mott, \& Lester, 2011). Akan tetapi dalam penerapannya $e$-learning juga memiliki kelemahan yaitu lemahnya kualitas dan kontrol terhadap pendidikan learning, seperti belum mampunya siswa mengelola waktu dan memproses informasi secara mandiri sehingga menjadi suatu permasalahan tersendiri bagi penyelenggara pendidikan e-learning. Sejalan dengan kebutuhan guru dalam mengatasi permasalahan proses pembelajaran pada mata pelajaran Fisika, maka dirasa perlu adanya suatu inovasi baru dalam pengembangan media pembelajaran yang mampu dikemas agar pembelajaran lebih menarik, interaktif dan efektif serta efesien dalam pemanfaatannya. Model komunikasi yang digunakan dalam pengajaran mungkin menjadi segmen paling penting yang menentukan efektivitas pembelajaran (Pećanac, Lambic \&Marić , 2011: 62).

Pendidikan harus dipahami, dan ini ada banyak paradigma dan teori (Garcia, W. \& MartinSanchez, M. 2013). Rancangan instruksional terdiri dari berbagai bentuk struktur adaptif dan proses pembelajaran, sementara tujuan pembelajaran sesuai dengan standard dasar akan diterapkan untuk membantu para peserta didik dalam menemukan inovasi (Kizilcec , Piech , \& Schneider, 2013). Pada model pengembangan yang nantinya akan di gunakan yaitu bersifat deskriptif yang menunjukkan langkah-langkah yang harus diikuti untuk menghasilkan produk berupa media pembelajaran diperoleh melalui data angket, tes dan wawancara. Para peserta didik lebih mungkin terlibat dalam aktivitas pembelajaran jika pelajaran tersebut terstruktur secara efektif dan menyenangkan (Awang, 2012).

\section{Model Pembelajaran Multimedia}

Ada terdapat beberapa format sajian model pembelajaran berbasis multimedia Interaktif seperti berikut:

\section{Model Tutorial}

Model tutorial merupakan salah satu model pembelajaran interaktif yang digunakan dalam proses belajar mengajar dengan menggunakan perangkat lunak atau software berupa program komputer berisi materi pelajaran. Tutorial dalam program multimedia interaktif ditujukan sebagai pengganti manusia sebagai instruktur pada kenyataannya. 


\section{Model Drills}

Model Drills merupakan salah satu bentuk model pembelajaran interaktif berbasis komputer (CBI) yang bertujuan memberikan pengalaman belajar yang lebih kongkret melalui penyediaan latihan-latihan soal untuk menguji penampilan siswa melalui kecepatan menyelesaikan soal yang diberikan program.

3. Model Simulasi

Model simulasi pada dasarnya merupakan salah satu strategi pembelajaan yang bertujuan memberikan pengalaman secara kongkret melalui penciptaan tiruantiruan bentuk pengalaman yang mendekati suasana sebenarnya dan berlangsung dalam suasana yang tanpa resiko.

4. Model Instructional Games

Model Instructional Games merupakan salah satu model dalam pembelajaran dengan multimedia interaktif yang berbasis komputer. Tujuan Model Instructional Games adalah untuk menyediakan suasana atau lingkungan yang memberikan fasilitas belajar yang menambah kemampuan siswa. Model Instructional game tidak perlu menirukan realita namun dapat memiliki karakter yang menyediakan tantangan yang menyenangkan bagi siswa. Multimedia interaktif terdari dari 3 tayangan, tayangan pembuka, tayangan inti, dan tayangan penutup (Hakim, M., Asrowi, A., \& Akhyar, A. 2018).

\section{METODE PENELITIAN}

Penelitian yang telah dilakukan adalah penelitian pengembangan dari beberapa penelitian sebelumnya, tahapan dari penelitian ini menggunakan model Metode (MDLC) Multimedia Development Life Cycle . Peneliti akan membuat pengembangan pembelajaran multimedia interaktif pada pelajaran fisika untuk pelajaran pokok bahasan Energi. Metode pengembangan (MDLC) yang akan dilakukan memiliki 6 (enam) tahapan yaitu, concept, design, collecting content material, assembly, testing dan distribution. pengembangan yang telah dijelaskan dibagian pendahuluan yaitu mempunyai tahapan melakukan perancangan analisis multimedia pada pembelajaran fisika adapun tahapannya berupa, Pengambilan data yang dilakukan dengan mengumpulkan berbagai materi - materi yang sesuai dengan kurikulum yang diterapkan pada sekolah tersebut. Studi literatur penelitian terkait tentang multimedia pembelajaran interaktif.

Perancangan sistem. Langkah awal yang dilakukan pada perancangan sistem adalah dengan membuat alur siklus diagram mengenai model pengembangan yang akan dipakai, dalam perancangan nantinya berupa text, audio, image, dan video. Selanjutnya dilakukan perancangan sistem menggunakan Adobe flash. Uji coba sistem dan analisa. Pada tahapan ini, sistem yang sudah dirancang selanjutnya di uji untuk melihat perkembangan dan kemajuan setelah dilakukannya perancangan. Selain itu, dilakukan juga proses analisa terhadap hasil parameter yang ada. Pembuatan laporan. tahapan terakhir yang 
dilakukan adalah melakukan penulisan laporan secara menyeluruh sebagai bahan publikasi dan laporan akhir penelitian.

Rancangan data inputan yang diperoleh dalam teknik yang digunakan pada model pengembangan multimedia guru nantinya melakukan kegiatan pengajaran menggunakan media interaktif. Pada setiap alur proses, nantinya guru bisa memilih sub pokok bahasan yang akan diberikan kepada anak didiknya yang berupa tampilan history fisika, silabus, pembahasan materi, video tutorial dan pemberian test soal. Dimana nantinya guru bisa memilih proses pembelajaran berupa materi-materi fisika yang ada, yang didalamnya terdapat proses animasi dan simulasi mengenai rumus fisika yang nantinya di perlihatkan kepada anak didiknya. Kemampuan pemikiran logis ini dicapai melalui kemampuan untuk mengelompokkan objek berdasarkan pada klasifikasinya (Zainuddin, Z. Ihsan, I.P (2013)).

Data yang dikumpulkan melalui pengamatan terhadap tindakan pembelajaran menggunakan media pembelajaran interaktif adalah hasil tes yang diberikan, yaitu kemampuan siswa dalam menjawab soal-soal pre-test dan post-test. Dan juga hasil observasi yang dilakukan selama proses pembelajaran berlangsung. Dalam penelitian ini penyajian data yang dilakukan dengan menggunakan analisis data yang bersifat deskriptif kuantitatif yaitu mendeskripsikan data yang diperoleh. Setelah data terkumpul lalu dikelompokkan 2 (dua) data, yaitu data kuantitatif yang berbentuk angka-angka dan data kualitatif yang dinyatakan dalam kata-kata. Teknik analisis data tersebut digunakan untuk mendeskripsikan perubahan hasil belajar dari sebelum sampai setelah pencapaian hasil belajar yang diharapkan dari segi keefektifan proses pembelajaran. Analisis ini juga digunakan untuk menggambarkan aktivitas siswa pada saat diterapkannya media pembelajaran pada proses pembelajaran.

Analisis ini juga digunakan untuk menggambarkan aktivitas peserta didik pada saat penerapan media instruksional dalam proses pembelajaran. E-learning dianggap mempengaruhi dalam proses transformasi dari pembelajaran konvensional kedalam pembelajaran digital (Zainuddin, Z. Manullang, E.V. 2013).

Untuk penyusunan data hasil tes dan menguji perbedaan rata-rata secara signifikan antara nilai siklus I dan siklus II setelah diberi perlakuan maka digunakan SPSS (Statistical Package and Social Siences) versi 16.0 for windows dengan menggunakan analisis uji t Pair Sample T Test. Jika Sig. (2tailed) $<0,05$ maka ada perbedaan yang signifikan antara nilai siklus I dan siklus II.

\section{HASIL PENELITIAN}

\section{Pelaksanaan Tindakan Siklus I}

Sebelum pelaksanaan tindakan siklus I dilakukan preetest terlebih dahulu. Kemudian pelaksanaan tindakan siklus I, guru menggunakan media pembelajaran Multimedia yang terdiri dari 2 kali pertemuan, pertemuan I guru memberikan materi Energy mekanik dan kinetik dengan siswa hadir semua.Pertemuan II masih melanjutkan materi Energy mekanik dan potensial dengan kehadiran semua siswa. Pertemuan I guru membawakan mata pelajaran Energy mekanik dan kinetik, dengan materi gaya 
beban dan percepatan yang pada awalnya disertai dengan pemberian masalah-masalah yang menggali pemikiran dan pengetahuan siswa terhadap materi yang dipelajari. Setelah itu, guru memperlihatkan gambar visualisasi mengenai Energy mekanik dan kinetik dengan menggunakan media pembelajaran Multimedia. Setelah itu, guru mengulas kembali gambar visualisasi tersebut dan menjelaskannya ke siswa, agar siswa lebih memahami dan mengerti tentang materi tersebut. Disamping itu, guru juga menggunakan model pembelajaran dan metode pembelajaran untuk membantu dalam proses pembelajaran. Dalam proses pembelajaran ini, guru membagi siswa menjadi 8 kelompokuntuk melihat dan mempelajari materi yang diberikan melalui media pembelajaran Multimedia agar bisa lebih memahami materi yang diberikan. Setiap siswa dalam kelompok diharapkan aktif dalam kegiatan diskusi kelompok dan menjelaskan materi yang diberikan melalui media Multimedia. Pada saat proses pembelajaran seperti ini, siswa diberikan waktu untuk tanya jawab antara kelompok dengan kelompok lainnya. Pada sesi tanya jawab inilah siswa akan berpendapat, bertanya, dan menjawab pertanyaan yang akan menambah keaktifan dalam proses pembelajaran. Guru sebagai penasehat dan pembimbing jalannya proses pembelajaran agar setiap siswa ikut aktif dalam kegiatan pembelajaran. Setelah selesai, guru mengulas kembali hasil dari siswa.

Pertemuan II guru melanjutkan materi dengan memberikan materi tentang Energy mekanik dan potensial. Guru menjelaskan materi Energy mekanik dan potensial dengan memperlihatkan gambargambar mengenai proses simulasi terhadap materi yang di berikan dan fungsinya yang terdapat pada media pembelajaran Multimedia. Kemudian guru mengadakan evaluasi siklus I dengan memberikan posttest. Hasil pretest dan posttest siklus I dapat dilihat pada lampiran 5. Tabel di bawah ini menunjukkan nilai terendah, nilai tertinggi, jumlah, nilai rata-rata, dan standar deviasi untuk pretest dan posttest siklus I.

Tabel 1 .Data hasil preetest dan posttest siklus I

\begin{tabular}{|c|c|c|c|c|c|c|}
\hline No & Tes & $\mathrm{N}$ & $\mathrm{X}_{\mathrm{min}}$ & $\begin{array}{c}\mathrm{X}_{\mathrm{ma}} \\
\mathrm{x}\end{array}$ & $\begin{array}{c}\text { Mea } \\
\mathrm{n}\end{array}$ & $\mathrm{SD}$ \\
\hline 1 & $\begin{array}{c}\text { Preetest } \\
\text { Siklus I }\end{array}$ & 38 & 35 & 70 & 57.37 & 8.010 \\
\hline 2 & $\begin{array}{c}\text { Posttest } \\
\text { Siklus I }\end{array}$ & 38 & 37.5 & 77.5 & 64.01 & 10.77 \\
\hline
\end{tabular}

Berdasarkan pelaksanaan penelitian diperoleh hasil pretest dan posttest yang kemudian akan diperoleh gain atau selisih antara pretest dan posttest. Berikut merupakan hasil pengolahan rata-rata hasil tes dari siklus I. 
Tabel 2. Rata-rata hasil pretest dan posttest siklus I

\begin{tabular}{|c|c|c|c|}
\hline No & Tes & Rata-rata & Gain \\
\hline 1 & Pretest Siklus I & 57.37 & \multirow{2}{*}{6.64} \\
\cline { 1 - 3 } 2 & Posttest Siklus I & 64.01 & \\
\hline
\end{tabular}

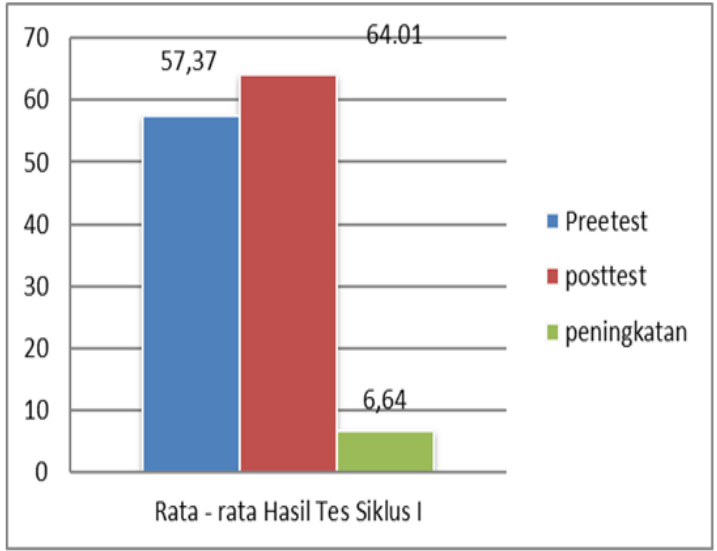

Gambar 1 . Grafik rata-rata hasil pretest dan posttest siklus I

Berdasarkan (Table 1) dan (Figure 1) di atas dapat diketahui bahwa terjadi peningkatan hasil belajar pada akhir siklus I terlihat dari nilai rata-rata pretest $=57.37$ meningkat pada posttest yaitu 64.01 dengan gain sebesar 6.64.

Kemudian berdasarkan perhitungan nilai t pada lampiran 9 maka diperoleh nilai $-\mathrm{t}_{\text {hitung }}=-3.492$ dan $-t_{\text {tabel }}=-3,431$, serta nilai Sig. $(2$-tailed $)=0.001$. Karena nilai $t_{\text {hitung }}<t_{\text {tabel }}$ dan Sig. $(2$-tailed $)<0.05$ maka terdapat perbedaan yang signifikan antara hasil pretest dan posttest siklus I.

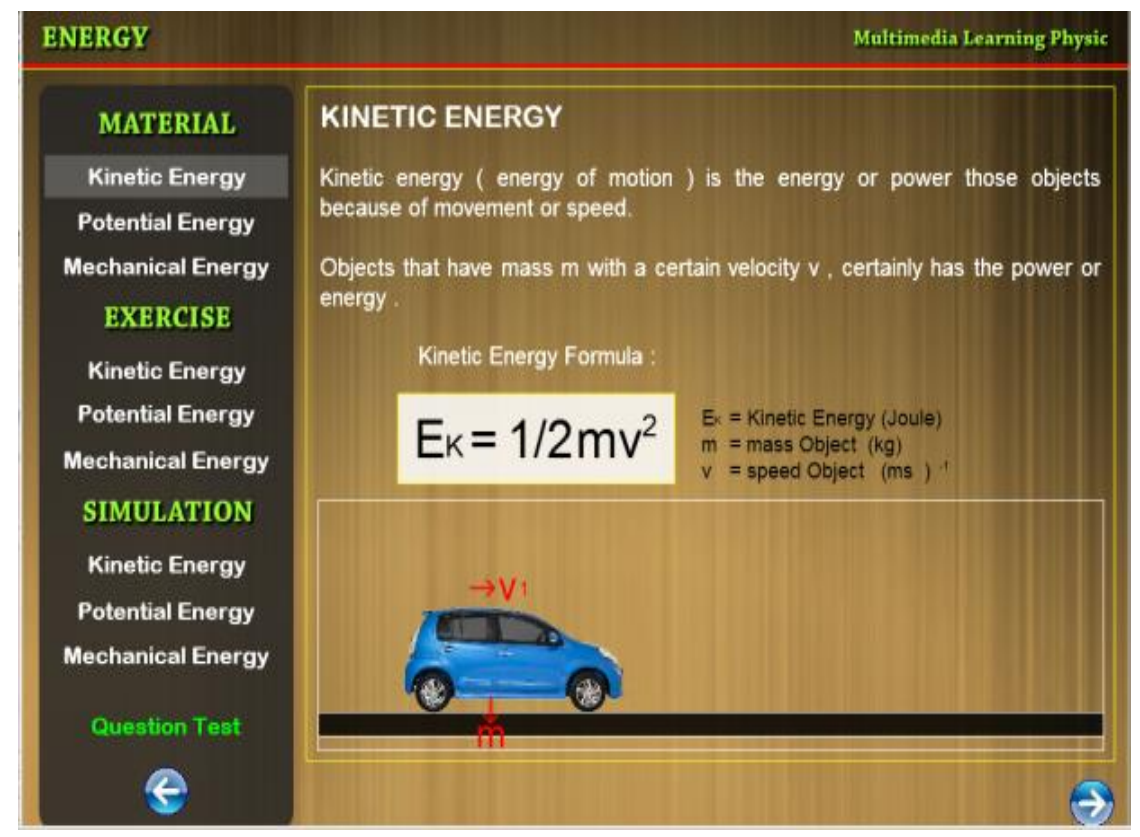

Gambar 2. Tampilan depan interaktif energy kinetik 


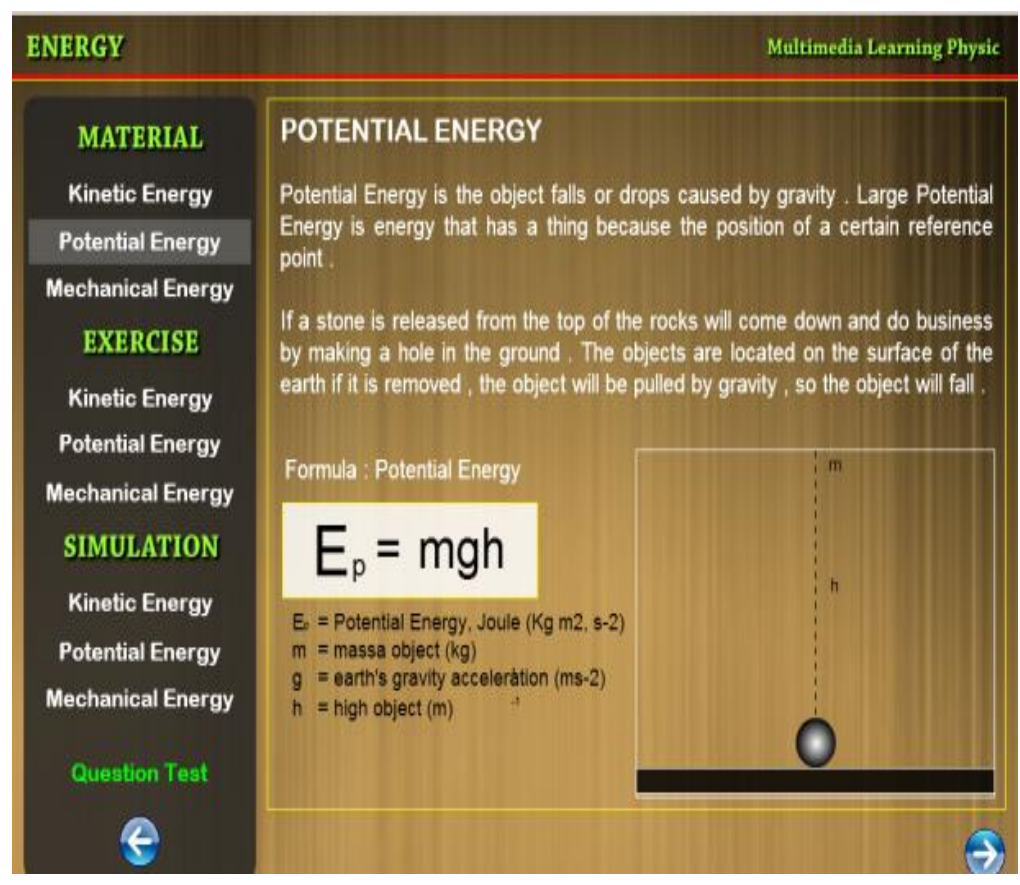

Gambar 3. Tampilan depan interaktif energy potensial

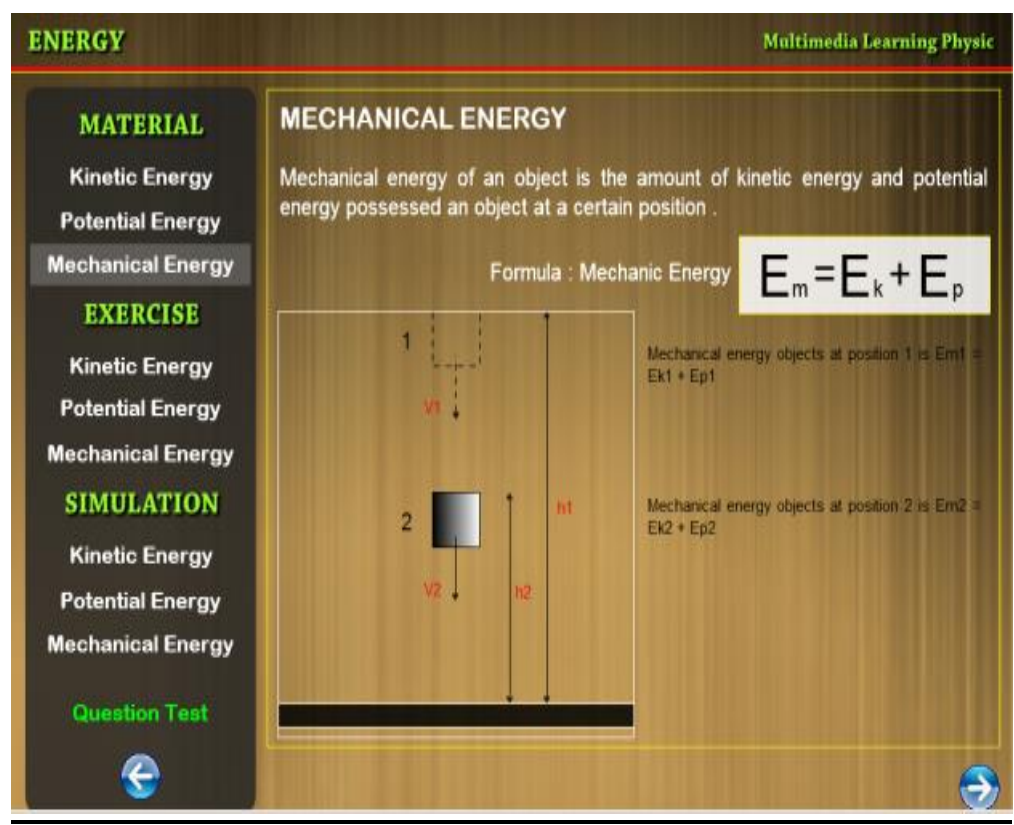

Gambar 4. Tampilan depan interaktif energy mekanik

Guru nantinya melakukan kegiatan pengajaran menggunakan media interaktif. Pada setiap alur proses, nantinya guru bisa memilih sub pokok bahasan yang akan diberikan kepada anak didiknya yang berupa tampilan materi, latihan, simulasi, dan pemberian test soal. Dimana nantinya guru bisa memilih proses pembelajaran berupa materi - materi fisika yang ada, yang didalamnya terdapat proses animasi dan simulasi mengenai rumus fisika yang nantinya di perlihatkan kepada anak didiknya. 


\section{Pelaksanaan Tindakan Siklus I}

Sebelum pelaksanaan tindakan siklus II dilakukan pretest terlebih dahulu. Kemudian pelaksanaan tindakan siklus II, guru menggunakan media pembelajaran Multimedia yang terdiri dari 2 kali pertemuan, pertemuan I guru melanjutkanmateriEnergy mekanik dan kinetik, dan pertemuan II guru memberikan materiEnergy Potensial dengan kehadiran siswa 100\%.Pertemuan I guru memberikan materi Energy Mekanik dan Energy Potensial dengan menggunakan media pembelajaran Multimediayang pada awalnya disertai dengan pemberian masalah-masalah yang menggali pemikiran dan pengetahuan siswa terhadap materi yang dipelajari.Dan guru juga masih menggunakan metode agar lebih memudahkan dan membantu dalam proses pembelajaran pada penggunaan media pembelajaran Multimedia. Kemudian guru membagi siswa menjadi 8 kelompok, untuk mempelajari dan lebih memahami materi yang diberikan dengan menggunakan media pembelajaran Multimedia. Setiap siswa dalam kelompok diharapkan aktif dalam kegiatan proses pembelajaran ini. Pada saat proses pembelajaran setiap kelompok diberikan waktu untuk tanya jawab antara kelompok dengan kelompok lainnya. Pada sesi tanya jawab inilah siswa akan berpendapat, bertanya, dan menjawab pertanyaan yang akan menambah keaktifan dalam proses pembelajaran.

Pertemuan II guru melanjutkan ke materi Energy Potensial dengan kegiatan yang sama dengan pada pertemuan I. Guru sebagai penasehat dan pembimbing jalannya presentasi agar setiap siswa ikut aktif dalam kegiatan pembelajaran. Setelah selesai, guru mengulas kembali hasil pembelajaran siswa. Kemudian guru mengadakan evaluasi siklus II dengan memberikan posttest. Hasil preetest dan posttest siklus II dapat dilihat pada lampiran Tabel di bawah ini menunjukkan nilai terendah, nilai tertinggi, jumlah, nilai rata-rata, dan standar deviasi untuk pretest dan posttest siklus II.

Table 3 . Data hasil pretest dan posttest siklus II

\begin{tabular}{|c|c|c|c|c|c|c|}
\hline No & Tes & $\mathrm{N}$ & $\mathrm{X}_{\min }$ & $\mathrm{X}_{\max }$ & Mean & SD \\
\hline 1 & $\begin{array}{c}\text { Pretest } \\
\text { Siklus } \\
\text { II }\end{array}$ & 38 & 40 & 77,00 & 65,13 & 10,206 \\
\hline 2 & $\begin{array}{c}\text { Posttest } \\
\text { Siklus } \\
\text { II }\end{array}$ & 38 & 42,00 & 85 & 74,00 & 8,440 \\
\hline
\end{tabular}

Berdasarkan pelaksanaan penelitian diperoleh hasil pretest dan posttest yang kemudian akan diperoleh gain atau selisih antara pretest dan posttest. Berikut ini merupakan hasil pengolahan rata-rata hasil tes dari siklus II. 
Table 4 . Rata-rata hasil pretest dan posttest siklus II

\begin{tabular}{|c|c|c|c|}
\hline No & Tes & Rata-rata & Gain \\
\hline 1 & Pretest Siklus II & 65,13 & \multirow{2}{*}{8,87} \\
\cline { 1 - 2 } 2 & $\begin{array}{c}\text { Posttest Siklus } \\
\text { II }\end{array}$ & 74,00 & \\
\hline
\end{tabular}

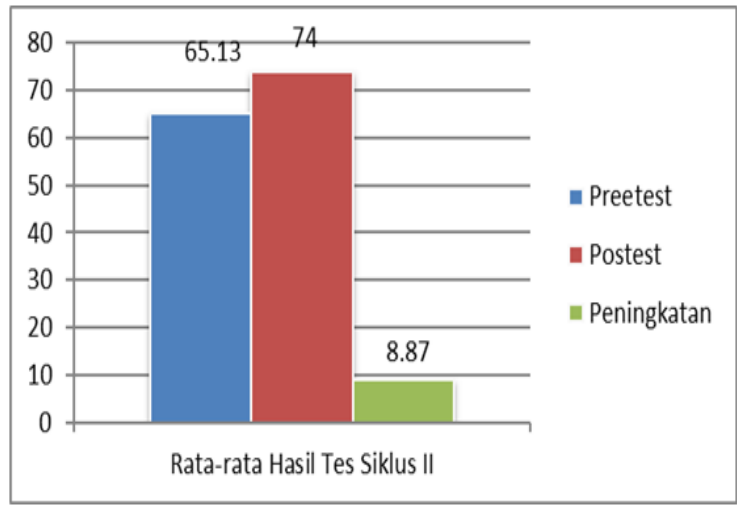

Gambar 5 . Grafik rata-rata hasil preetest dan posttest siklus II

Berdasarkan tabel dan gambar di atas dapat diketahui bahwa terjadi peningkatan hasil belajar pada akhir siklus II terlihat dari nilai rata-rata preetest $=65,13$ meningkat pada posttest yaitu 74,00 dengan gain sebesar 8,87.

Kemudian berdasarkan perhitungan nilai t pada lampiran 9 maka diperoleh nilai $-\mathrm{t}_{\text {hitung }}=-6,354$ dan $-\mathrm{t}_{\text {tabel }}=-1,690$ serta nilai Sig. $(2$-tailed $)=0.00$. Karena nilai $\mathrm{t}_{\text {hitung }}>\mathrm{t}_{\text {tabel }}$ dan Sig. $(2$-tailed $)<0.05$ maka terdapat perbedaan yang signifikan antara hasil preetest dan posttest siklus II.

\section{Perbandingan Hasil Observasi Siklus I dan Siklus II}

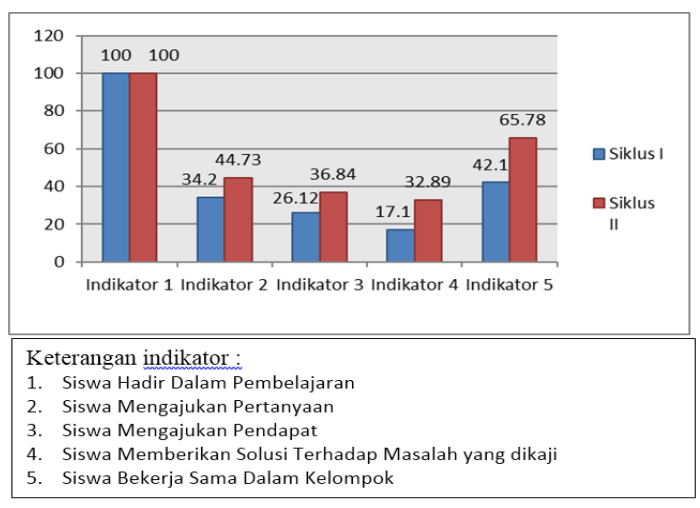

Gambar 6. Grafik persentase perbandingan hasil observasi keaktifan siswa tiap siklus 
Dapat dilihat bahwa terjadi peningkatan keaktifan siswa selama proses pembelajaran dilihat dari meningkatnya jumlah persentase masing-masing indikator keaktifan siswa pada akhir setiap siklusnya. Jumlah persentase indikator siswa hadir pada siklus I dan siklus II sebesar 100\%. Jumlah persentase indikator siswa mengajukan pertanyaan meningkat sebesar 10,53\% dari siklus I sebesar $34,20 \%$ menjadi $44,73 \%$ pada siklus II. Jumlah persentase indikator siswa mengajukan pendapat meningkat sebesar $10,72 \%$ dari siklus I sebesar 26,12\% menjadi $36,84 \%$ pada siklus II. Kemudian, jumlah persentase indikator siswa yang memberikan solusi terhadap masalah yang dikaji meningkat sebesar 15,79\% dari siklus I sebesar 17,10\% menjadi 32,89\% pada siklus II. Dan jumlah persentase indikator siswa bekerja sama dalam kelompok meningkat sebesar 23,68\% dari siklus I sebesar 42,10\% menjadi $65,78 \%$ pada siklus II.

\section{PEMBAHASAN}

Proses pembelajaran yang mampu membangkitkan keinginan siswa untuk belajar harus dikondisikan, misalnya dengan penyajian masalah-masalah real (kontektual) yang ada di sekitar siswa yang terkait dengan materi yang dikaji. Hal ini dimaksud kan untu membangun pemahaman siswa. Pemecahan masalah-masalah kontektual yang mungkin sudah dialami siswa akan dapat menumbuhkan ketrampilan berpikir tingkat tinggi bagi siswa. Masalah-masalah kontektual tersebut dapat dikemas dalam bentuk pembelajaran media pembelajaran berupa modul. Pembelajaran berbasis modul dapat didesain dalam bentuk teks, video, atau animasi. Modul sejenis itu sering disebut dengan modul multirmedia. Modul multimedia didesain dalam bentuk teks, video atau animasi dapat dipergunakan untuk menunjukkan situasi real yang lebih meyakinkan siswa dalam memahami konsep daripada desain dalam bentuk teks cetak, gambar, atau grafik dalam desain konvensional. Fenomena yang berhubungan dengan kehidupan masyarakat di lingkungan dimana siswa itu berada akan lebih memudahkan pemahaman siswa belajar terhadap konsep fisis yang sedang mereka pelajari. Siswa sebaiknya sudah mengenal fenomena real yang dialami. Misalnya, siswa akan lebih mudah menjelaskan konsep energy dengan memberi contoh simulasi energy kinetic dan energy mekanik. Dengan modul multimedia dapat memberi peluang kepada siswa untuk memfasilitasi siswa bertanya dan memahami konsep, serta merupakan alat komunikasi yang efektif. Sebuah animasi memberikan lebih banyak informasi dibandingkan dengan obyek diam atau deskripsi suatu gerakan, karena animasi menunjukkan semua aspek gerak pada setiap saat.

Hasil penelitian menunjukkan bahwa terjadi peningkatan nilai rata-rata hasil tes siswa pada masing-masing siklus. Berdasarkan hasil preetest di siklus I diperoleh bahwa tidak ada siswa yang lulus, disebabkan karena siswa tidak memiliki dasar dan masih kurangnya pengetahuan mengenai penginstalan komputer. Oleh karena itu, untuk meningkatkan hasil belajar siswa, guru memberikan tindakan penggunaan media pembelajaran Multimedia selama proses pembelajaran. Hasil posttest yang diberikan pada akhir siklus I diperoleh siswa yang lulus sebanyak 13 dari 38 siswa. Penelitian dilanjutkan ke siklus II karena masih terdapat siswa yang belum lulus. Pada awal siklus II, siswa 
diberikan preetest diperoleh siswa yang lulus sebanyak 15 siswa. Sebelum pelaksanaan siklus II dilakukan perbaikan media pembelajaran yang akan digunakan pada siklus II. Hasil dari posttest siklus II yang hanya diikuti 35 siswa dari 38 siswa menunjukkan bahwa siswa yang lulus sebanyak 31 siswa. Pada Posttest ini yang seharusnya diikuti 38 siswa, namun hanya 35 siswa yang mengikuti dan 3 siswa yang tidak ikut. Ketidakhadiran ke-3 siswa ini, disebabkan karena mereka terlibat dalam suatu kegiatan sekolah yang mengharuskan mereka untuk mengikutinya.

Berdasarkan hasil analisis data menunjukkan terjadi peningkatan pada siklus I sebesar 7,69 dan pada siklus II sebesar 9,12. Meningkatnya hasil belajar siswa tersebut disebabkan karena selama proses pembelajaran, guru menerapkan media pembelajaran Multimedia. Penggunaan Multimedia lebih memudahkan siswa dalam memahami materi pembelajaran yang disampaikan.Selain itu, guru juga menggabungkan beberapa metode mengajar yaitu metode ceramah, diskusi kelompok, tanya jawab dan praktek. Sehingga dengan menerapkan beberapa metode tersebut dapat membuat siswa aktif dalam hal mengajukan pertanyaan-pertanyaan, mengajukan pendapat jika ada pertanyaan, memberikan solusi terhadap masalah-masalah yang dikaji dan aktif dalam kerja sama kelompok.

Berdasarkan hasil penelitian yang dilakukan oleh Baharuddin (2014), mengenai pengaruh media pembelajaran diperoleh hasil bahwa penggunaan media pembelajaran berbasis Multimedia memiliki pengaruh yang tinggi terhadap hasil belajar siswa, jika dibandingkan dengan hasil belajar yang menggunakan media gambar yaitu nilai rata - rata sebesar 89,17 untuk media berbasis Multimedia sedangkan untuk media gambar nilai rata-rata 82,08. Penggunaan media berbasis Multimedia lebih baik digunakan jika dengan media gambar terhadap hasil belajar siswa.

Hasil penelitian ini juga menunjukkan bahwa jumlah persentase indikator siswa hadir pada siklus I sebesar 96,04\% dan pada siklus II sebesar 100\%. Jumlah persentase indikator siswa mengajukan pertanyaan meningkat sebesar 10,53\% dari siklus I sebesar 34,20\% menjadi $44,73 \%$ pada siklus II. Jumlah persentase indikator siswa mengajukan pendapat meningkat sebesar $10,72 \%$ dari siklus I sebesar 26,12\% menjadi 36,84\% pada siklus II. Kemudian, jumlah persentase indikator siswa yang memberikan solusi terhadap masalah yang dikaji meningkat sebesar 15,79\% dari siklus I sebesar $17,10 \%$ menjadi 32,89\% pada siklus II. Dan jumlah persentase indikator siswa bekerja sama dalam kelompok meningkat sebesar 23,68\% dari siklus I sebesar $42,10 \%$ menjadi $65,78 \%$ pada siklus II. Hal ini menunjukkan terjadi peningkatan keaktifan siswa selama proses pembelajaran yang ditunjukkan dengan meningkatnya jumlah persentase masing-masing indikator pada setiap siklusnya. Peningkatan ini menunjukkan bahwa penggunaan media pembelajaran Multimedia dapat membuat siswa lebih antusias dan lebih aktif dalam mengikuti proses pembelajaran, Hasil yang sama juga diungkap oleh peneliti terdahulu seperti: Garofalo (2009), Lirong Xiao (2013), dan Gokhan Aksoy (2012)

Peningkatan keaktifan siswa tersebut juga disebabkan karena siswa dapat belajar mandiri bersama kelompoknya maupun secara individu dalam memecahkan masalah yang diberikan oleh guru yang menggunakan beberapa metode mengajar, antara lain metode ceramah, diskusi kelompok, tanya jawab dan praktek. Dengan menggunakan metode mengajar tersebut membantu siswa menjadi lebih 
mandiri dalam mencari informasi tentang materi yang dipelajari, informasi dapat dicari di berbagai media pembelajaran baik dari buku, internet maupun media yang lain.

\section{KESIMPULAN}

Berdasarkan hasil penelitian yang diperoleh, maka dapat ditarik kesimpulan bahwa dengan menggunakan media pembelajaran Berbasis multimedia interaktif dapat meningkatkan hasil belajar siswa sekolah menengah atas pada pelajaran fisika terkhusus pokok bahasan energy. Ini terlihat dari peningkatan nilai rata-rata hasil tes siswa pada masing-masing siklus I dan siklus II. Disamping itu, keaktifan siswa selama proses pembelajaran meningkat dengan adanya pengembangan multimedia interaktif.

Berdasarkan hasil penelitian ini, dapat diajukan saran-saran penelitian, sebagai berikut.

Keterampilan guru dalam menggunakan modul pembelajaran multimedia perlu ditingkatkan melalui pelatihan,agar bisa menyesuaikan dan membiasakan diri untuk menggunakan media dalam proses pembelajaran.

(2). Pengembangan modul multimedia interaktif seperti ini perlu dilakukan untuk materi dan mata pelajaran yang lain, sehingga perkembangan TIK yang begitu pesat, dapat dimanfaatkan untuk mendukung proses pembelajaran di sekolah, karena hampir di setiap ruangan kelas disediakan LCD. (3). Fasilitas TIK yang ada di sekolah perlu ditingkatkan, karena masih ada SMA yang memiliki laboratorium dengan jumlah computer yang masih kurang.

\section{UCAPAN TERIMA KASIH}

Penelitian ini didukung oleh Multimedia Research Group Team Universitas Muhammadiyah Makassar Fakultas Teknik.

\section{DAFTAR PUSTAKA}

Aksoy, Gokhan. (2012). The Effects of Animation Technique on the 7th Grade Science and Technology Course.Creative Education. June 2012. Vol.3, No.3, 304-308

Alessi, S. \& Trollip, S. (2001). Multimedia for learning. New Jersey: Allyn and Bacon

Awang, M.M. (2012). An Exploration of Strategies Used by Malaysian Secondary School Teachers to Promote Positive Behaviour: Professionals' and Students' Perspectives. PhD Thesis. University of Dundee, United Kingdom

BakracevicVukman K. and Licardo M. (2010). How cognitive, metacognitive, motivational and emotional self-regulation influence performance in adolescence and young adulthood.Educational Studies, 36 (3), 259 - 268.

Garcia, W. \& Martin-Sanchez, M. (2013). Hermeneutics and pedagogy: educational practicein the speech about Education. Pulso.Revista de Educacion, 36, 55 - 78. 
Garofalo, Joe. (2009). Macromedia Flash as a Tool for Mathematics Teaching and Learning. School Science and Mathematics, Feb 2009, 104, 2; ProQuest pg. 89-93.

Gunter, R. D. 2010. Multimedia Learning: Are Still Asking the Questions? Journal of Educational Multimedia and Hypermedia, 19 (1): 103-120.

Gürses, A and Doğar, Ç (2013). Interactive Direct Teaching Based Constructivist Learning (IDTBCL). International Conference on Education and Social Sciences.

Hakim, M., Asrowi, A., \& Akhyar, A. (2018, December 31). Pengembangan Multimedia Interaktif Mata Pelajaran Bahasa Arab Materi Profesi Bagi Siswa Kelas VIII SMP IT Al-Huda Wonogiri. JTP - Jurnal Teknologi Pendidikan,20(3), 249 - 263. Retrieved from http://journal.unj.ac.id/unj/index.php/jtp/article/view/9537

Heru, T. (2010).Multimedia Interactive.Djogja: Andi.

Kizilcec, R.F., Piech, C., \& Schneider, E. (2013).Deconstructing Disengagement: Analyzing Learner Subpopulations in Massive Open Online Courses.In Proceedings of the Third International Conference on Learning Analytics and Knowledge (pp. 170 -179).ACM.

Kirschner, P. A.; Sweller, J.; Clark, R. E. (2006). Why minimal guidance during instruction does not work: an analysis of the failure of constructivist, discovery, problem-based, experiential, and inquiry-based teaching". Educational Psychologist 41 (2): 75-86.

McKagan et al. (2008). "Developing and Researching PhET simulations for Teaching Quantum Mechanics". American Journal of Physics, (76) pp. 406 - 417.

Onintra, P. 2009. Evaluation of Educational Multime-dia Support System for Students with Deaf-ness. Journal of Educational Multimedia and Hy-permedia, 8(1): 71-90.

Pallares, M. (2013).Advertising as a school learningtool.RevistaIberoamericana de Educacion, 61 (1)

Pećanac, R., Lambić, D., \&Marić, M. (2011).The Influence of the Use of Educational Softwareon the Effectiveness of Communication Models in Teaching. The New EducationalReview, 26(4), 60 -70 .

Seok, Soonhwa. (2008). The aspect of e-learning. International Journal on ELearning, Proquest, 7(4), 725-741.

Sisco, Ashley. (2010). Nations First for e-learning of effectiveness the Optimizing. Ottawa: The Conference Board of Canada.

Spires, H. A., Rowe, J. P., Mott, B. W., \& Lester, J. C. (2011). Problem solving and game-based learning: effects of middle grade students' hypothesis testing strategies on science learning outcomes. Journal of Educational Computing Research, 44, 453-472.

Xiao, Lirong. (2013). Animation Trends in Education. International Journal of Information and Education Technology, Vol. 3, No. 3, June 2013. 286-289

Zainuddin, Z.,Ihsan, I.P. (2013). Modelling of child psychology tests based game learning. Proceedings of 2013 IEEE International Conference on Teaching, Assessment and Learning for Engineering. (pp. 715-719).TALE 
Zainuddin, Z.,Manullang, E.V. (2013). E-lerning concept design of rijndael encryption process. Proceedings of 2013 IEEE International Conference on Teaching, Assessment and Learning for Engineering. (pp. 737-741).TALE 